\title{
Perlindungan Hukum Bagi Buruh Dalam Sistem Hukum Ketenagakerjaan Nasional
}

\author{
Suhartoyo \\ Fakultas Hukum, Universitas Diponegoro \\ suhartoyo@live.undip.ac.id
}

\begin{abstract}
The research aims to find out the legal protection for workers in the national labor law system. The research method used is normative legal research that uses the regulatory approach. the results of the study show that legal protection for workers in the national labor law system includes: 1). Protection about wages, welfare, labor social security; 2). Occupational safety and health protection; 3). Legal protection to form and become a member of a trade union / labor union; 4). Protection of basic rights of workers / laborers to negotiate with entrepreneurs.
\end{abstract}

Keywords: Legal protection, Labor, Labor law system

\begin{abstract}
Abstrak
Penelitian bertujuan untuk mengetahui perlindungan hukum bagi buruh dalam sistem hukum ketenagakerjaan nasional. Metode penelitian yang digunakan adalah penelitian hukum normatif yang menggunakan pendekatan peraturan perundang undangan. hasil penelitian menunjukan bahwa perlindungan hukum bagi buruh dalam sistem hukum ketenagakerjaan nasional meliputi: 1). Perlindungan tentang upah, kesejahteraan, jaminan sosial tenaga kerja; 2). Perlindungan keselamatan dan kesehatan kerja; 3). Perlindungan hukum untuk membentuk dan menjadi anggota serikat Pekerja/ serikat buruh; 4). Perlindungan atas hak-hak dasar pekerja / buruh untuk berunding; dengan pengusaha.
\end{abstract}

Kata kunci: Perlindungan hukum, Buruh, Sistem hukum ketenagakerjaan

\section{A. Pendahuluan}

Di Indonesia dalam era reformasi, informasi dan globalisasi seperti sekarang ini, telah berdiri banyak macam perusahaan yang bergerak di berbagai bidang, jenis usaha dan industri. Sehingga persaingan antar perusahaan menjadi sangat ketat. Para pengusaha dalam menyikapi hal ini, mereka melakukan beberapa hal yang dapat mendukung dalam menghasilkan barang produksinya lebih baik dan berkualitas,sehingga tujuan dari 
perusahaan tercapai. Salah satu hal yang diterapkan untuk mencapai tujuan tersebut pengusaha lebih mengoptimalkan para pekerja/buruhnya dalam meningkatkan produktivitas kerja.

Jumlah Pekerja /Buruh di Indonesia pada Agustus 2018 mencapai lebih dari 100 juta Orang (tepatnya 124,01 juta). ini menjadikan jumlah pekerja /buruh di Indonesia hampir separo dari jumlah penduduk Indonesia, maka Pekerja/Buruh tentu saja mempunyai arti yang sangat penting bagi Indonesia baik bagi Pemerintah, Perusahaan dan masyarakat Menyadari arti pentingnya pekerja/buruh bagi perusahaan, pemerintah dan masyarakat,maka perlu dilakukannya suatu pemberian perlindungan hukum bagi buruh. Perlindungan hukum dapat diwujudkan dalam bentuk materi (kesejahteraan pekerja/buruh) tetapi juga dalam bentuk pencegahan terhadap terjadinya kecelakaa, oleh karena hal terbut merupakan hal yang sangat penting agar pekerja dapat menjaga kesehatan dan keselamatannya di dalam menjalankan pekerjaan.

Pemikiran - pemikiran itu merupakan program perlindungan pekerja, yang pada akhirnya tidak hanya dapat memberi kuntungan pekerja/buruh tetapi itu juga pada akhirnya menguntungkan perusahaan karena peberlangsungan pada produksi dan produktivitas dapat terjamin. Melihat pentingnya pekerja /buruh dan perlunya memberikan perlindungan kepada pekerja/buruh maka dalam tulisan ini mengambil permasalahan: Bagaimanakah perlindungan hukum bagimpekerja/buruh yang diberikan Undang-Undang nomor 13 tahun 2003 tentang ketenagakerjaan.

\section{B. Pembahasan}

Ketenagakerjaan atau Perburuhan diatur dalam Undang-Undang Nomor 13 Tahun 2003 tentang Ketenagakerjaan, yang diundangkan pada Lembaran Negara Tahun 2003 Nomor 39 pada tanggal 25 Maret 2003, dan mulai berlaku pada tanggal diundangkan. Menurut Undang-Undang Nomor 13 Tahun 2003 yang dimaksud dengan 'Tenaga kerja' adalah setiap orang 
yang mampu melakukan pekerjaan guna menghasilkan barang dan atau jasa baik untuk memenuhi kebutuhan sendiri maupun masyarakat.

Selanjutnya pengertian Pekerja atau Buruh adalah setiap orang bekerja dengan menerima upah atau imbalan dalam bentuk apapun. Pengertian ini agak umum, namun maknanya lebih luas karena karena dapat mencakup semua orang yang bekerja pada siapa saja, baik perorangan, persekutuan, badan hukum, atau badan lainnya dengan menerima upah atau imbalan dalam bentuk apapun. Penegasan imbalan dalam bentuk apapun ini perlu karena upah selama ini diidentikkan dengan uang, padahal ada pula buruh/pekerja yang menerima imbalan dalam bentuk barang.

Hukum Ketenagakerjaan mengatur hubungan kerja antara pekerja/buruh dengan pengusaha, yang berarti mengatur kepentingan orang perorangan. Hubungan kerja yang mengatur antara pekerja dan pengusaha pada dasarnya memuat hak dan kewajiban dari para pihak. Pengertian hak dan kewajiban selalu bersifat timbal balik antara satu dengan yang lain. Hak pekerja atau buruh merupakan kewajiban pengusaha. Demikian pula sebaliknya. Hubungan kerja tidak terlepas dari perjanjian kerja yang dibuat oleh para pihak. Dalam hukum Indonesia, ada yang menterjemahkan dengan perjanjian dan ada pula yang menterjemahkan dengan perikatan.

Hak dan kewajiban yang telah ditetapkan dalam perjanjian harus dilaksanakan dengan sebaik mungkin. Jangan sampai salah satu pihak melakukan pelanggaran. Dalam Undang-Undang no. 13 tahun 2003 tentang Ketenagakerjaan, diatur mengenai hubungan kerja ini, di mana hubungan kerja yang terbentuk antara Pekerja/Buruh dengan Pengusaha/ Perusahaan harus diwujudkan dalam bentuk: Perjanjian Kerja; Perjanjian kerja Waktu tidak tertentu (PKWT); Perjanjian Kerja Waktu Tertentu (PKWTT); Peraturan Perusahaan; Perjanjian Kerja Bersama; Perjanjian Pemborongan;

Perlindungan kerja bertujuan untuk menjamin berlangsungnya sistem hubungan kerja tanpa disertai adanya tekanan dari pihak yang kuat kepada pihak yang lemah.. Secara yuridis dalam Pasal 5 Undang-Undang Nomor 13 Tahun 2003, yaitu memberikan perlindungan bahwa setiap tenaga kerja 
berhak dan mempunyai kesempatan yang sama untuk memperoleh pekerjaan dan penghidupan yang layak tanpa membedakan jenis kelamin, suku, ras, agama, dan aliran politik sesuai dengan minat dan kemampuan tenaga kerja yang bersangkutan, termasuk perlakuan yang sama terhadap para penyandang cacat.Sedangkan dalam Pasal 6 Undang-Undang Nomor 13 Tahun 2003, mewajibkan para pengusaha untuk memberikan hak dan kewajiban pekerja atau buruh tanpa membedakan jenis kelamin, suku, ras, agama dan aliran politik.

Lingkup perlindungan terhadap pekerja / buruh menurut Undang-Undang Nomor 13 Tahun 2003, antara lain secara garis besar meliputi: 1.Perlindungan tentang upah, kesejahteraan, jaminan sosial tenaga kerja; 2. Perlindungan keselamatan dan kesehatan kerja; 3. Perlindungan hukum untuk membentuk dan menjadi anggota serikat; Pekerja/ serikat buruh; 4. .Perlindungan atas hak-hak dasar pekerja / buruh untuk berunding; dengan pengusaha;

\section{Perlindungan Upah Dan Jaminan Sosial Tenaga Kerja}

Upah memegang peranan yang sangat penting dan merupakan ciri khas dari suatu hubungan kerja bahkan dikatakan upah merupakan tujuan utama dari seorang pekerja yang melakukan pekerjaan pada orang atau badan hukum lain. Karena itulah pemerintah turut serta dalam menangani masalah pengupahan ini melalui berbagai kebijakan yang dituangkan dalam Peraturan Perundang-undangan.

Setiap tenaga kerja berhak memperoleh penghasilan yang layak bagi kemanusiaan. Untuk mewujudkan penghasilan yang layak, pemerintah menetapkan perlindungan dengan pengupahan bagi pekerja. Perwujudan penghasilan yang layak dilakukan pemerintah melalui penetapan upah minimum atas dasar kebutuhan yang layak. Pengaturan pengupahan ditetapkan atas dasar kesepakatan antara pengusaha dan pekerja. ${ }^{1}$

${ }^{2}$ B. Siswanto Sastrohadiwiryo, Manajemen Tenaga Kerja Indonesia Pendekatan Administrasi dan Operasional, Cet. 2, hlm. 15 
Pengupahan termasuk salah satu aspek yang paling penting dalam perlindungan pekerja atau buruh. Hal ini secara tegas, dijelaskan dalam Pasal 88 ayat (1) Undang-Undang Nomor 13 Tahun 2003 bahwa setiap pekerja atau buruh berhak memperoleh penghasilan yang memenuhi penghidupan yang layak bagi kemanusiaan. Menurut Pasal 1 angka 30 Undang-undang Nomor 13 Tahun 2003 yang dimaksud dengan upah adalah hak pekerja atau buruh yang diterima dan dinyatakan dalam bentuk uang sebagai imbalan dari pengusaha atau pemberi kerja kepada pekerja atau buruh yang ditetapkan dan dibayarkan menurut perjanjian kerja, kesepakatan, atau peraturan perundang-undangan, termasuk tunjangan bagi pekerja atau buruh dan keluarganya atas suatu pekerjaan dan atau jasa yang telah atau akan dilakukan.

Berdasarkan Peraturan Menteri Tenaga Kerja Nomor PER01/MEN/1999 jo. Keputusan Menteri Tenaga Kerja dan Transmigrasi Nomor KEP-226/MEN/2000 jangkauan wilayah berlakunya upah minimum meliputi : Upah minimum Provinsi (UMP) berlakunya diseluruh kabupaten atau kota dalam 1 (satu) wilayah propinsi; Upah minimum kabupaten atau kota (UMK) berlaku dalam 1 ( satu ) wilayah kabupaten atau kota.

Jaminan sosial tenaga kerja adalah suatu bentuk perlindungan yang diberikan kepada pekerja dan keluarganya terhadap berbagai resiko yang dialami tenagakerja. Jumlah angkatan kerja di Indonesia sangat besar, yaitu sekitar 100 juta orang akan terus tumbuh lebih dari 2 (dua) persen pertahun. ${ }^{2}$ Bentuk Perlindungan Jaminan Sosial Tenaga kerja sekarang diwujudkan dalam Undang-Undang Nomor : 40 tahun 2004 tentang Sistim Jaminan Sosial Nasional dan Undang-Undang Nomor : 24 tahun 2011 tentang BPJS , yang terdiri dari BPJS Kesehatan dan BPJS Ketenagakerjaan. Jadi Sekarang Bentuk perlindungan, pemeliharaan dan peningkatan kesejahteraan dalam masa sekarang ini diselenggarakan oleh Badan Pnyelenggara Jaminan Sosial (BPJS).

\footnotetext{
${ }^{3}$ Lalu Husni, Pengantar Hukum Ketenagakerjaan Indonesia Edisi Revisi,, Cet. 4, PT. Raja Grafindo Persada, jakarta, 2003, hal. 152.
} 
Dan BPJS sekarang ini meliputi BPJS Kesehatan dan BPJS Ketenagakerjaan yang merupakan kelanjutan dari Jaminan Sosial Tenaga kerja yang dahulunya dilaksanakan oleh PT. Jamsostek . Yang dimaksud dengan Jaminan Sosial Tenaga Kerja adalah suatu perlindungan bagi tenaga kerja dalam bentuk Pemberian Jaminan kesehatan dan juga santunan berupa uang sebagai pengganti sebagian dari penghasilan yang hilang atau berkurang dan pelayanan sebagai akibat peristiwa atau keadaan yang dialami oleh tenaga kerja berupa kecelakaan kerja, sakit, hamil, bersalin, hari tua, dan meninggal dunia.

\section{Kesehatan dan Keselamatan Kerja}

Dalam Pasal 86 ayat (1) huruf (a) Undang-Undang Nomor 13 Tahun 2003 tentang kesehatan kerja merupakan salah satu hak pekerja atau buruh untuk itu pengusaha wajib melaksanakan secara sistematis dan terintergrasi dengan sistem manajemen perusahaan. Upaya kesehatan kerja bertujuan untuk melindungi pekerja atau buruh guna mewujudkan produktivitas kerja yang optimal, dengan cara pencegahan kecelakaan dan penyakit akibat kerja, pengendalian bahaya ditempat kerja, promosi kesehatan, pengobatan, dan rehabilitasi.

Dengan demikian tujuan kesehatan kerja adalah : Melindungi pekerja dari resiko kecelakaan kerja; Meningkatkan derajat kesehatan para pekerja/buruh; Agar pekerja atau buruh dan orang-orang disekitarnya terjamin kesehatannya; Menjamin agar produksi dipelihara dan dipergunakan secara aman dan berdaya guna. Berkaitan dengan kesehatan kerja maka setiap pengusaha wajib melaksanakan ketentuan-ketentuan sbb :

\section{Waktu Kerja}

Waktu kerja sebagaimana dimaksud dalam Pasal 77 Ayat (1) Undang-Undang Nomor 13 Tahun 2003 yang meliputi : a.7 (tujuh) jam 1 (satu) hari dan 40 (empat puluh) jam 1 (satu) minggu untuk 6 (enam) hari kerja dalam 1 (satu) minggu; atau b.8 (delapan) jam 1 (satu) hari dan 40 (empat puluh) jam 1 (satu) minggu 5 (lima) hari kerja dalam 1 (satu) minggu. Selebihnya dari Waktu kerja itu dimungkinkan utk kerja lembur 
Maksimal 3 jam dalam 1 hari maka untuk itu pengusaha wajib Membayar upah lembur sesuai ketentuan Menaker No.102 tahun 2004.

\section{Waktu Istirahat}

Pengusaha juga wajib memberikan waktu istirahat dan cuti kepada pekerja atau buruh :

a. Istirahat mingguan 1 (satu) hari untuk 6 (enam) hari kerja dalam 1 (satu) minggu atau 2 (dua) hari untuk 5 (lima) hari kerja dalam 1 (satu) minggu;

b. Istirahat antara jam kerja, sekurang-kurangnya setengah jam setelah bekerja selama 4 (empat) jam terus menerus dan waktu istirahat tersebut tidak termasuk jam kerja;

c. Cuti tahunan, sekurang-kurangnya 12 (dua belas) hari kerja setelah pekerja atau buruh yang bersangkutan bekerja selam 12 (duabelas) bulan secara terus menerus;

d. Istirahat panjang sekurang-kurangnya 2 (dua) bulan dan dilaksanakan pada tahun ketujuh dan kedelapan masing-masing 1 (satu) bulan bagi pekerja atau buruh yang telah bekerja selama 6 (enam) tahun secara terus menerus pada perusahaan yang dengan ketentuan pekerja atau buruh tersebut tidak berhak lagi atas istirahat tahunannya dalam 2 (dua) tahun berjalan dan selanjutnya berlaku untuk setiap kelipatan masa kerja 6 (enam) tahun.

Kesehatan kerja ini merupakan cara agar buruh melakukan pekerjaan yang layak bagi kemanusiaan dan tidak hanya ditujukan terhadap pengusaha yang hendak mengeksplotasi pekerja/buruh, tetapi juga ditujukan terhadap pihak pekerja/ buruh itu sendiri.

\section{Keselamatan Kerja}

Dengan majunya industrialisasi, mekanisme, dan modernisasi, maka dalam kebanyakan hak berlangsung pulalah peningkatan intesitas kerja operasional dan tempat kerja para pekerja. Hal ini memerlukan pengerahan tenaga kerja secara intensif pula dari para pekerja. Hal tersebut dapat 
menyebabkan Kelelahan, kurang perhatian akan hal-hal ini, kehilangan keseimbangan dan lain-lain merupakan akibat dari padanya dan sebab terjadinya kecelakaan maka perlu dipahami perlu adanya pengetahuan keselamatan kerja yang tepat, selanjutnya dengan peraturan yang maju akan dicapai keamanan yang baik dan realistis yang merupakan faktor yang sangat penting dalam memberikan rasa tenteram, kegiatan dan kegairahan bekerja pada tenaga kerja yang bersangkutan dalam hal ini dapat mempertinggi mutu pekerjaan, peningkatan produksi dan produktivitas kerja.

Keselamatan kerja adalah keselamatan yang bertalian dengan mesin, pesawat alat kerja, bahan dan proses pengolahannya, landasan tempat kerja dan lingkungannya, serta cara-cara melakukan pekerjaan. Obyek keselamatan kerja adalah segala tempat kerja, baik didarat, didalam tanah, dipermukaan air, didalam air maupun di udara. Dalam Pasal 1 UndangUndang Nomor 1 Tahun 1970 Tentang Keselamatan Kerja, dijelaskan tentang adanya 3 (tiga) unsur : Tempat dimana dilakukan pekerjaan bagi sesuatu usaha; Adanya tenaga kerja yang bekerja disana; Adanya bahaya kerja di tempat itu.

Sedangkan dalam Pasal 6 Undang-Undang Nomor 1 Tahun 1970 dijelaskan tentang kecelakaan kerja adalah kecelakaan yang terjadi berhubung dengan hubungan kerja, demikian pula kecelakaan yang terjadi dalam perjalanan berangkat dari rumah menuju tempat kerja, dan pulang ke rumah melalui jalan atau wajar dilalui.

\section{Perlindungan Hukum Bagi Pekerja /Buruh Untuk Membentuk dan} Menjadi Anggota Serikat pekerja/serikat buruh.

Serikat Pekerja/serikat buruh adalah organisasi yang dibentuk dari, oleh dan untuk pekerja /buruh baik di perusahaan maupun di luar perusahaan, yang bersifat bebas,terbuka, mandiri, demokratis dan bertanggungjawab guna memperjuangkan, membela serta melindungi hak dan kepentingan pekerja/buruh serta meningkatkan kesejahteraan pekerja/buruh dan keluarganya. 
Perlindungan hukum berkaitan dengan hak pekerja/buruh untuk membentuk dan menjadi anggota serikat pekerja/serikat buruh terdapat Pada pasal 104 UU no.13 tahun 2003. Pasal 104 ayat 1 menyebutkan :

“Setiap pekerja/ buruh berhak membentuk dan menjadi anggota serikat pekerja/ serikat buruh". Pekerja/buruh yang tergabung dalam serikat pekerja/serikat buruh berhak untuk mengelola keuangan serta mempertanggungjawabkan keuangan organisasi termasuk dana mogok. Ketentuan dalam pasal 104 UU No.13 tahun 2003 ini sejalan dengan ketentuan Undang-undang Nomor . 21 tahun 2000 tentang Serikat Pekerja/Serikat Buruh khususnya pasal 5 ayat 1 yang bunyinya sama dengan pasal 104 ayat 1 UU NO.13 tahun 2003. Bahkan Perlindungan Hukum terhadap pekerja /buruh dalam UU No.21 tahun 2000 diwujudkan dalam bentuk kemudahan untuk membentu k Serikat / Serikat buruh, di mana pekerja / Buruh minimal 10 (sepuluh) orang sudah berhak membentuk serikat pekerja/serikat buruh.

\section{Perlindungan Atas Hak-Hak Dasar Pekerja / Buruh Untuk}

\section{Berunding Dengan Pengusaha;}

Hukum Ketenagakerjaan mengatur hubungan kerja antara Pekerja / buruh dan pengusaha, yang berarti mengatur kepentingan orang perorangan. Hubungan kerja yang mengatur antara pekerja/buruh dan pengusaha pada dasarnya memuat hak dan kewajiban dari para pihak. Pengertian hak dan kewajiban selalu bersifat timbal balik antara satu dengan yang lain. Hak pekerja atau buruh merupakan kewajiban bagi pengusaha, demikian pula sebaliknya hak pengusaha juga merupakan kewajiban pekerja/buruh.Untuk mewujudkan hal tersebut maka dalam UU No. 13 tahun 2003 tentang Ketenagakerjaan dalam pasal 106 telah diatur mengenai suatulembaga yang merupakan forum komunikasi dan berunding bagi pekerja/buruh dengan pengusaha yaitu dengan adanya suatu lembaga Bipartit. Lembaga Bipartit ini berfungsi sebagai forum komunikasi dan konsultasi mengenai hal ketenagakerjaan di suatu Perusahaan . Adapun keanggotaan Lembaga Bipartit terdiri dari unsur 
pengusaha dan unsur pekerja/buruh yang ditunjuk oleh pekerja/buruh secara demokratis untuk mewakili kepentingan dari pekerja/buruh di perusahaan yang bersangkutan.. Lembaga Bipartit juga sebagai lembaga pertama untuk menyelesaikan sengketa antara pekerja / buruh dengan pengusaha.

Undang-Undang No. 13 tahun 2003 tentang Ketenagakerjaan dalam pasal 107 juga mengatur mengenai hak berunding yang lain dalam sebuah lembaga Kerjasama Tripartit yang berfungsi hampir sama dengan lembaga Bipartit. Lembaga Tipartit ini berfungsi memberikan pertimbangan, saran dan pendapat kepada pemerintah dan pihak terkait termasuk pekerja/buruh dan pengusaha ,dalam penyusunan kebijakan dan pemecahan masalah ketenagakerjaan . Keanggotaan Lembaga Kerjasama Tripartit terdiri dari unsur pemerintah, organisasi pengusaha dan serikat pekerja/serikat buruh yang mewakili pekerja/buruh. Lembaga Kerjasama Tripartit ini terdiri Lembaga Kerjasama Tripartit Nasional, Propinsi dan Kabupaten /Kota , serta Lembaga Kerjasama Tripartit Sektoral Nasional, Propinsi dan Kabupaten/Kota.

\section{Simpulan}

Hasil penelitian menunjukan bahwa perlindungan hukum bagi buruh dalam sistem hukum ketenagakerjaan nasional meliputi: 1). Perlindungan tentang upah, kesejahteraan, jaminan sosial tenaga kerja; 2). Perlindungan keselamatan dan kesehatan kerja; 3). Perlindungan hukum untuk membentuk dan menjadi anggota serikat Pekerja/ serikat buruh; 4). Perlindungan atas hak-hak dasar pekerja / buruh untuk berunding; dengan pengusaha.

Sebagai contoh jaminan sosial tenaga kerja yang suatu bentuk perlindungan yang diberikan kepada pekerja dan keluarganya terhadap berbagai resiko yang dialami tenagakerja. Jumlah angkatan kerja di Indonesia sangat besar, yaitu sekitar 100 juta orang akan terus tumbuh lebih dari 2 (dua) persen pertahun. 
Sedangkan perlindungan kesehatan kerja dapat melindungi dalam hal: 1). Melindungi pekerja dari resiko kecelakaan kerja; 2). Meningkatkan derajat kesehatan para pekerja/buruh; 3). Agar pekerja atau buruh dan orangorang disekitarnya terjamin kesehatannya; 4). Menjamin agar produksi dipelihara dan dipergunakan secara aman dan berdaya guna.

\section{Daftar Pustaka}

Anizar,, Tehnik Keselamatan dan Kesehatan kerja di Industri, Yogyakarta: Graha Ilmu, 2014).

Asikin, Zainal, Dasar-Dasar Hukum Perburuhan (Jakarta :PT. Raja Grafindo Persada, 2009)

Asyhadi, Zaeni , Hukum Kerja : Hukum Ketenagakerjaan Bidang Hubungan Kerja (Jakarta : Raja Grafindo Persada , 2007)

B.Siswanto, Sastrohadiwiryo, Manajemen Tenaga Kerja Indonesia pendekatan Administrasi dan Operasional, Cet. 2, (Bandung : Penerbit PT.Citra Aditya,2010)

Husni, Lalu, Pengantar Hukum Ketenagakerjaan Indonesia Edisi Revisi,, Cet. 4, (PT. Raja Grafindo Persada, jakarta, 2003)

Keputusan Menteri Tenaga Kerja dan Transmigrasi Nomor KEP226/MEN/2000 Upah Minimum

Keputusan Menteri Tenaga Kerja dan Transmigrasi RI Nomor KEP102/MEN/2004 tentang Waktu Lembur da n Upah Lembur

Khakim, A., Pengantar Hukum Ketenagakerjaan Indonesia. (Bandung: Penerbit PT. Citra Aditya, 2014).

Sugiman, Hak-Hak Perlindungan Hukum Terhadap Tenaga Kerja Di Indonesia. (Bandung: Rineka Cipta, 2015)

Undang-Undang Nomor : 24 tahun 2011 tentang BPJS

UndangUndang Nomor : 40 tahun 2004 tentang Sistim Jaminan Sosial Nasional

Undang-Undang Nomor 13 Tahun 2003 tentang Ketenagakerjaan

Undang-Undang Nomor 2 Tahun 2004 tentang Penyelesaian Perselisihan Hubungan Industrial

Undang-Undang Nomor 21 tahun 2000 tentang Serikat Pekerja/ Serikat Buruh

Widjaya, I., Hukum Perusahaan. (Jakarta: Kesaint Blanc, 2015) 